\title{
THE RITUAL YEAR OF THE ICON OF THE ANNUNCIATION ON THE ISLAND OF TINOS, GREECE
}

\author{
Evy Johanne Håland
}

\begin{abstract}
After several mystical visions of the nun, Pelagia, the holy icon of the Annunciation of the Blessed Virgin (Panagia) was found in 1823. According to tradition, Pelagia repeatedly witnessed the Panagia in her visions where she received orders from her to find the Virgin's icon and also to build her church. The icon was unearthed in the field where it had remained since the church, built on the ruins of a pagan temple, was destroyed in the 10th century. Two years before the icon was found, the Greek War of Independence broke out. The finding of the icon, the construction of the Church of the Panagia, Euangelistria, the enormous crowds of pilgrims and all the miracles worked by the icon, contributed to the outcome that the island was declared a sacred island, and Pelagia became sanctified.

The ritual year of the miraculous icon on Tinos starts on 30 January with the festival dedicated to the Finding of the Icon. The next festival is dedicated to the Day of the Annunciation of the Virgin Mary. This day has both a religious and a national ideological significance, since 25 March is celebrated as Independence Day. July 23 is dedicated to the "Vision" of Saint Pelagia. The most important festival, the Dormition of the Panagia, is celebrated on 15 August.

During the festivals official processions, carrying the icon in its midst, are important, but also popular customs related to the importance of fetching holy water and earth as well as the other symbols which have a long tradition within Greek religions.

Accordingly, the article aims to present the ritual year of the miraculous icon on Tinos, thus exploring the relation between official and popular religion. Since several of the rituals and symbols recur across many religious groupings in the Middle East and Mediterranean, they might be studied from a comparative perspective, thus transcending European heritages: liberating the ethnological imagination. ${ }^{1}$
\end{abstract}

Key words: death-cult, earth, fertility-cult, festivals, Greece, healing, icon, Mediterranean, official and popular religion, saint, water

\section{INTRODUCTION}

In 1823, after several mystical visions by one of the islanders, a pious nun named Pelagia, there was found the Miraculous holy icon (image) of the Annunciation (Euangelismos) of the Virgin Mary (Megalochari, megalo: 'great', 


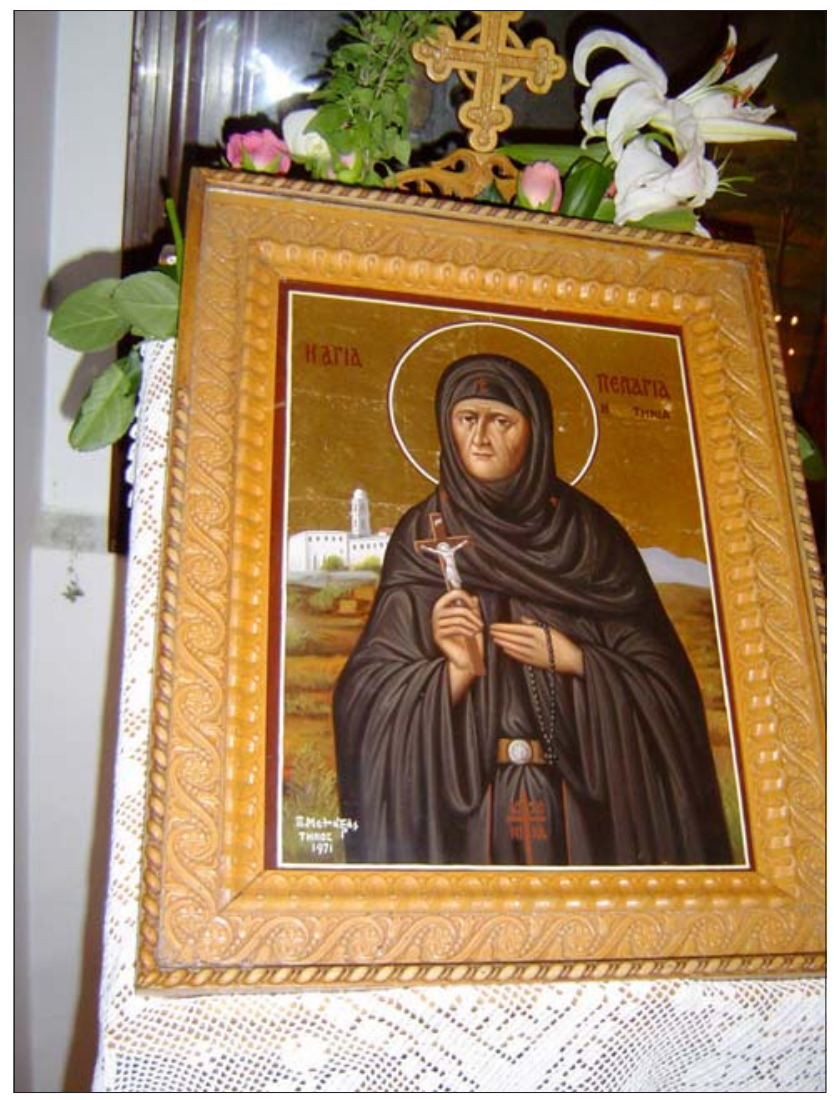

Figure 1. Agia (Saint) Pelagia in the Monastery of Kechrovounios, Tinos island. Photo by Evy Johanne Håland.

charē: 'grace', i.e. the Blessed Virgin). According to the tradition, Pelagia repeatedly saw, in her visions, the Panagia (i.e. the 'All-Holy one'), who ordered her to inform the elders to start digging with an aim to find Panagia's icon, buried many years ago in an uncultivated field, and to build her "house" (i.e. her church) on that place. On 30 January 1823, the icon was unearthed in the field where it had remained for about 850 years, since the church, built on the ruins of the pagan temple of Dionysos, was destroyed and burned down by the Saracens in the 10th century AD. Two years before the icon was found, the great Greek War of Independence (1821) broke out and the finding of the icon, the construction of the Church of the Annunciation, the enormous crowds of pilgrims and all the miracles worked by the icon, contributed to the result that in 1971, the island was declared a sacred place by governmental decree. Pelagia also became sanctified (Fig. 1) on 11 September 1970. 


\section{JANUARY: ANNIVERSARY OF THE FINDING OF THE HOLY ICON}

All religious festivals, within the orthodox liturgical year, are of course celebrated on Tinos, but resulting from the history of the island, some festivals are more important than others. Thus, though the ritual year on Tinos follows the agricultural calendar normally celebrated within the Orthodox Church and begins around autumn, by the end of the dead period of the grains' cycle, as I have illustrated elsewhere (Håland 2005, 2006a, 2007a), the ritual year of the miraculous icon on Tinos starts on 30 January with the Anniversary of the Finding of the Holy Icon.

This festival is dedicated to Euresēs, i.e. the Finding (of the Holy Icon), and during the festival the finding of the icon is re-enacted. ${ }^{2}$ The festival starts in the afternoon on the eve of the anniversary, when the icon is carried from the main church to the minor church or chapel below, which is called Zoodochos $P \bar{e} g \bar{e}$, i.e. the 'Life-giving Spring', or the 'Life-giving Well'. The inhabitants of Tinos however, call the chapel, Euresēs ('Finding'). Here, the icon is placed at the site where it lay buried for hundreds of years. A special service is held, dedicated to the Finding of the Holy Icon.

On 30 January, an official liturgy is celebrated in the main church in the afternoon and afterwards the icon is carried in procession through the decorated streets of the town. After a ceremony in the harbour, the icon is carried back to the church, where a ceremony is held in memory of the builders of the church, whose tombs are situated at the east side of the building. Prayers are also said in memory of those who lost their lives and fortunes for the construction of the church. After vespers, the president of the church committee delivers the panegyric of the day, provides a report of the activities of the holy foundation during the past year and those that are planned for the following year.

In the evening, children holding multicoloured lighted lamps, follow the church musicians through the streets of Tinos, singing various hymns commemorating the finding of the holy icon. Several pilgrims participate in the festival as well, although more visitors arrive for the next festival during the ritual year of the miraculous icon on Tinos.

\section{MARCH: THE ANNUNCIATION OF THE VIRGIN MARY}

The next festival is dedicated to the Day of the Annunciation of the Virgin Mary, on 25 March. This day has both a religious and a national (political) ideological significance, since 25 March is celebrated as Independence Day, 
marking the liberation of Greece from Turkish rule. This festival, celebrating the anniversary of the Greek revolution, was the most important festival on Tinos in the 19th century, whereas at the beginning of the 20th century, many pilgrims came from Asia Minor, i.e. modern Turkey. ${ }^{3}$ Likewise, government officials always participate in this event. The festival is particularly related to the important and dominant symbol of the island, the Miraculous Icon of the Annunciation of the Virgin. The icon is attributed to the apostle and evangelist Luke, who is believed to have painted it during Mary's lifetime, with her as a living model, thus, tying it to the very origins of Christianity and the image directly to Mary herself. It shows Gabriel appearing before Mary with the announcement of Christ's birth, i.e. the icon announces fertility. Today, the icon is covered with offerings of gold and precious stones, and it is not possible to see what it portrays. The miracles worked by the holy icon have made Tinos a centre of Pan-Orthodox worship, some them are more famous than others, and several miracles are said to have happened during the olonychtia, 'the allnight-service' or all night long prayers of 25 March. As generally happens within the Orthodox Church, the festival starts on the eve of the celebration when vespers are performed and the church remains open all night, permitting people to stay for an all-night prayer vigil. On the day of the festival a liturgy is celebrated, afterwards the icon is carried in procession to the harbour and back to the church. The Annunciation is also the name of the church of the Panagia and the street by which most of pilgrims descend after completing their proskynema (i.e. to perform the set of devotions a pilgrim does upon entering the church).

\section{JULY: ANNIVERSARY OF THE VISION OF AGIA PELAGIA}

The third important festival is celebrated in July and is dedicated to one of the most recent Orthodox saints, the aforementioned, Agia (Saint) Pelagia. "Her Vision" is celebrated on 23 July. During the festival the ritual connection between the Monastery of Kechrovounios, where she lived, and the Church of the Annunciation in the city of Tinos, is marked by way of a procession with the miraculous icon (Fig. 2).

On the eve of the festival a liturgy is celebrated in the Church of the Annunciation, which is crowded by the islanders, and all those coming home to Tinos for their summer holidays. The icon of Pelagia is decorated with flowers and burning candles, and plays a main role during the liturgy together with the miraculous icon. Pelagia also has a chapel dedicated to her below the main church. Her icon is situated in front of the stones from earlier sanctuaries 


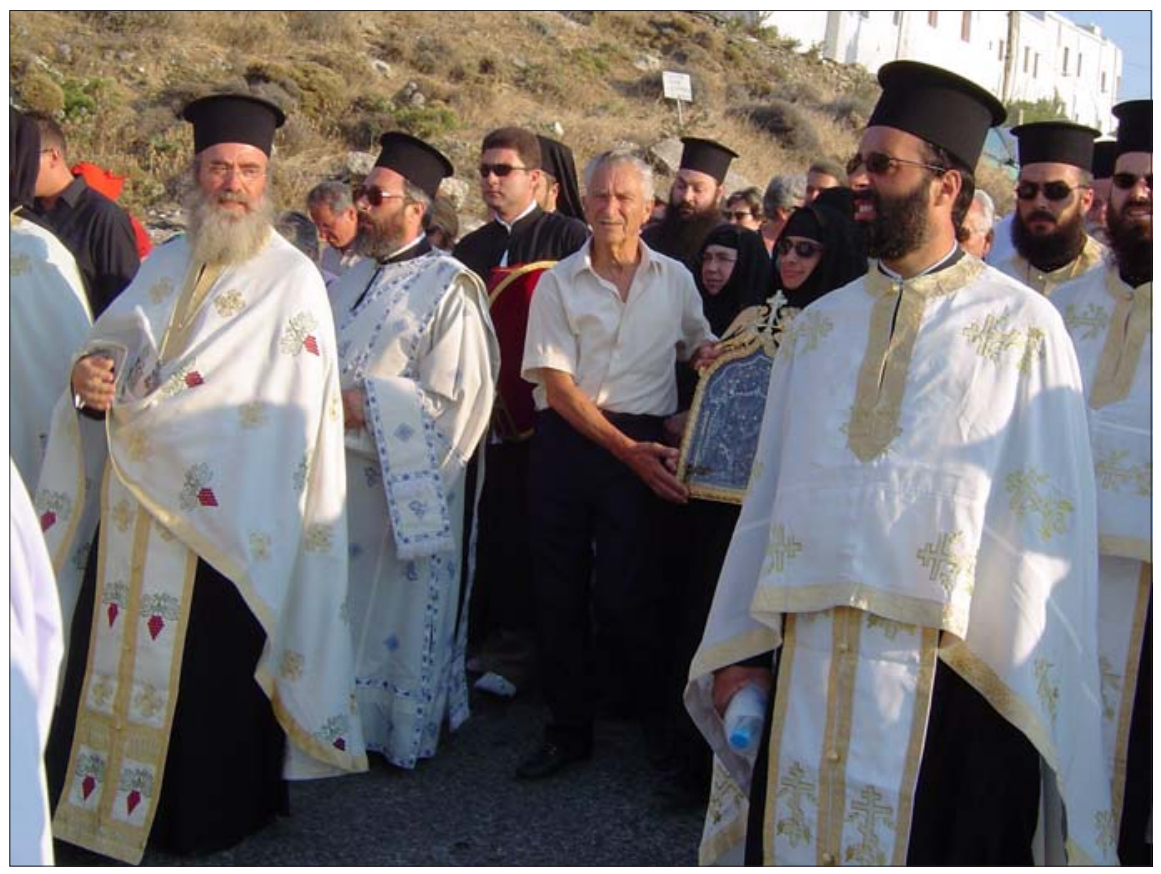

Figure 2. The miraculous icon of the Annunciation is carried in procession from the Monastery of Kechrovounios, Tinos island, 23 July. Photo by Evy Johanne Håland.

which were removed when the miraculous icon was unearthed. Although the Church of the Annunciation wanted to have her bones when these were disinterred three years after her death (as is the general rule within the Orthodox Church), her remains however, i.e. her head, are still in the Monastery of Kechrovounios, where she had her visions in 1822 (Kardamitsē 1992; Karita s.a.).

Early the next morning, headed by the church musicians, the miraculous icon is carried in procession, accompanied by the nuns of the monastery and islanders to the harbour and then taken by taxi to the Monastery of Kechrovounios, dedicated to the Dormition of the Panagia, where it remains all day. A mass is celebrated, followed by a lunch "served by the abbess" to all the participants, the most significant visitors receiving the most elaborate meals. Most people stay in the monastery all day, taking the opportunity to visit the cell of Agia Pelagia, seeing her humble belongings and her ascetic bed. Three years after her death, when she was disinterred, the nuns hid her remains since they did not want them to be buried outside the monastery. At a later date her head was found buried in a chapel dedicated to John the Baptist. After lunch several women perform their own liturgy in this church, when a group of women join in singing hymns to Pelagia in front of the iconostasis where 


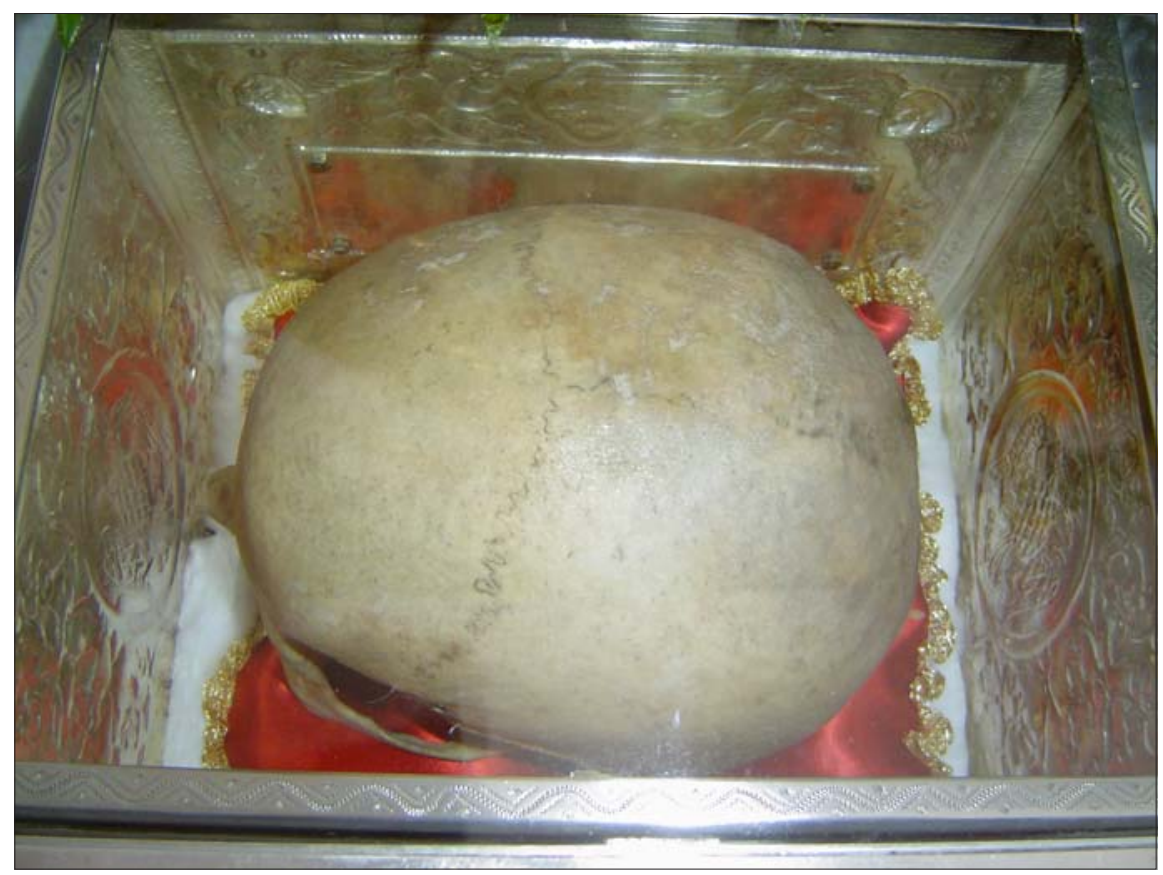

Figure 3. The holy head of Pelagia in her church in the Monastery of Kechrovounios, Tinos island. Photo by Evy Johanne Håland.

her skull was found. Today, her holy head is seen in the church next to her cell where a liturgy is celebrated in the afternoon (Fig. 3). Later, during a nine kilometre procession taking several hours and consisting of the clergy and many faithful, the holy icon is returned to the Church of the Annunciation in the town of Tinos. Arriving late at night, the icon and the whole procession are welcomed by fireworks, torches and ships' bells, sirens and buses' horns. The miraculous icon is returned to the church after sermons and speeches, on a podium positioned by the waterfront, thus bringing to an end this very picturesque local festival.

\section{AUGUST: THE DORMITION OF THE VIRGIN MARY}

The most important festival on modern Tinos is also the most significant PanHellenic festival - dedicated to the Dormition of the Panagia, the Bearer or Mother of God (i.e. E Koimēsis tēs Theotokou), which is celebrated on $15 \mathrm{Au}-$ gust, marking the end of the fifteen-day fast in honour of the Panagia. The feast of the Dormition began in the seventh century, and in Greek Orthodoxy it still retains the name. 
Figure 4. Pilgrims on their knees are making their way up to the Church of the Annunciation on the top of the hill, Tinos island. Photo by Evy Johanne Håland.

All year pilgrims come to Tinos, but the enormous crowd of devotees is greatest during the days of the Augustfestival (Fig. 4). The Dormition of the Panagia is also an important ideological festival, combining the celebration of the Dormition with the day of the armed forces. This is illustrated through several ceremonies during the festival: The service is followed by a procession at 11 a.m. when the miraculous icon is carried down the main street. Government top cabinet members and the head of the Greek Orthodox Church, followed by clergy and notables, are present, accompanied by a military escort and lesser officials. A detachment of sailors marches at the tail of the procession; the national Hellenic Navy always sends warships to Tinos on 15 August, because the Panagia represents the intimate and hazardous relations of the Greeks towards the sea. The Navy is honoured because it is "under the protection of the Virgin". The national ideology is also manifested through the speeches given by the authorities, and by the posters displayed in the town, announcing the festival. The Panagia is, for example, hovering over the na-

Figure 5. A poster proclaiming 15 August as the "Day of the Armed Forces", Tinos island. Photo by Evy Johanne Håland.
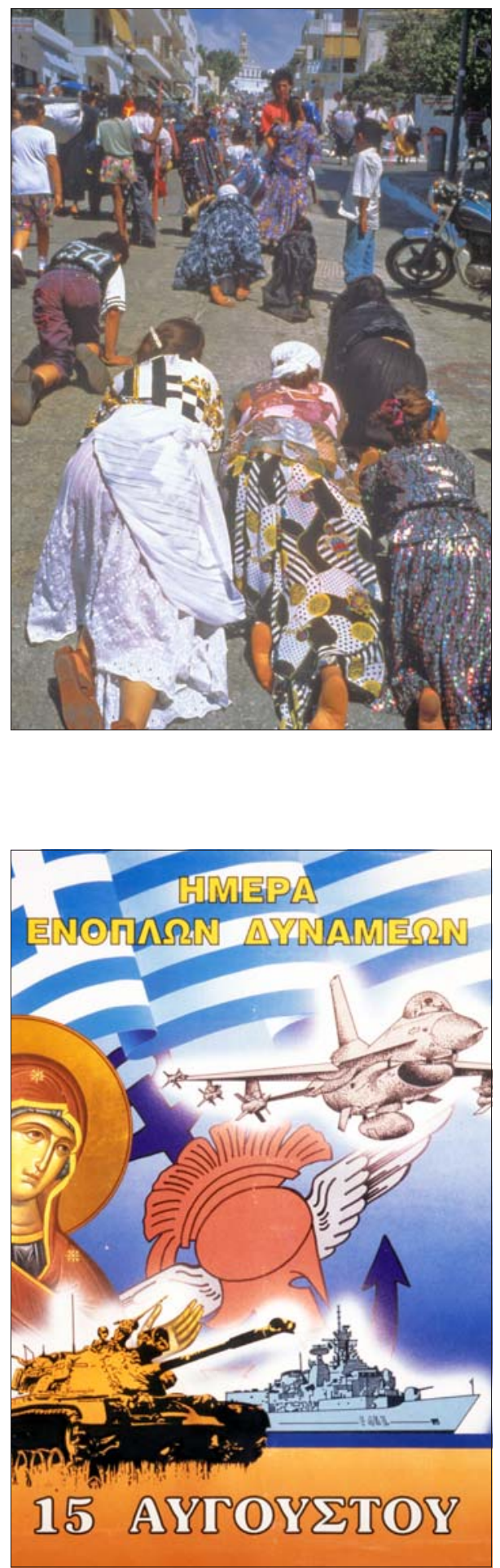
tional symbol, the Acropolis of Athens. Another poster may depict a mixing of modern and ancient symbols (Fig. 5). The message is always the same: 15 August is proclaimed as the "Day of the Armed Forces", and the symbols of the navy, the air force and the army are illustrated. We meet the double nature of the occasion as both a national and religious holiday, in agreement with the traditional close connection between the official Orthodox Church and the nation-state, in a patriotic sense.

Her icon is carried in procession, and is also passed over the sick and women wanting to conceive (Fig. 6). Several hours before the service is finished, a long queue of pilgrims forms in the street waiting for the icon, and as the icon is carried down the street they stand, bending down in its path, so that the icon may pass over them. It is important to touch and kiss the icon. In addition to the crowd of followers, thousands of onlookers watch the procession, several on their knees, some holding incense burners or lit candles. Several sick pilgrims lie down, as the custom was earlier, but today they are in danger of being trampled over. During the procession jets are regularly flying over the island, accompanied by the salutes fired by the warships and the cannon at the memorial in the harbour, which was inaugurated in 2002.

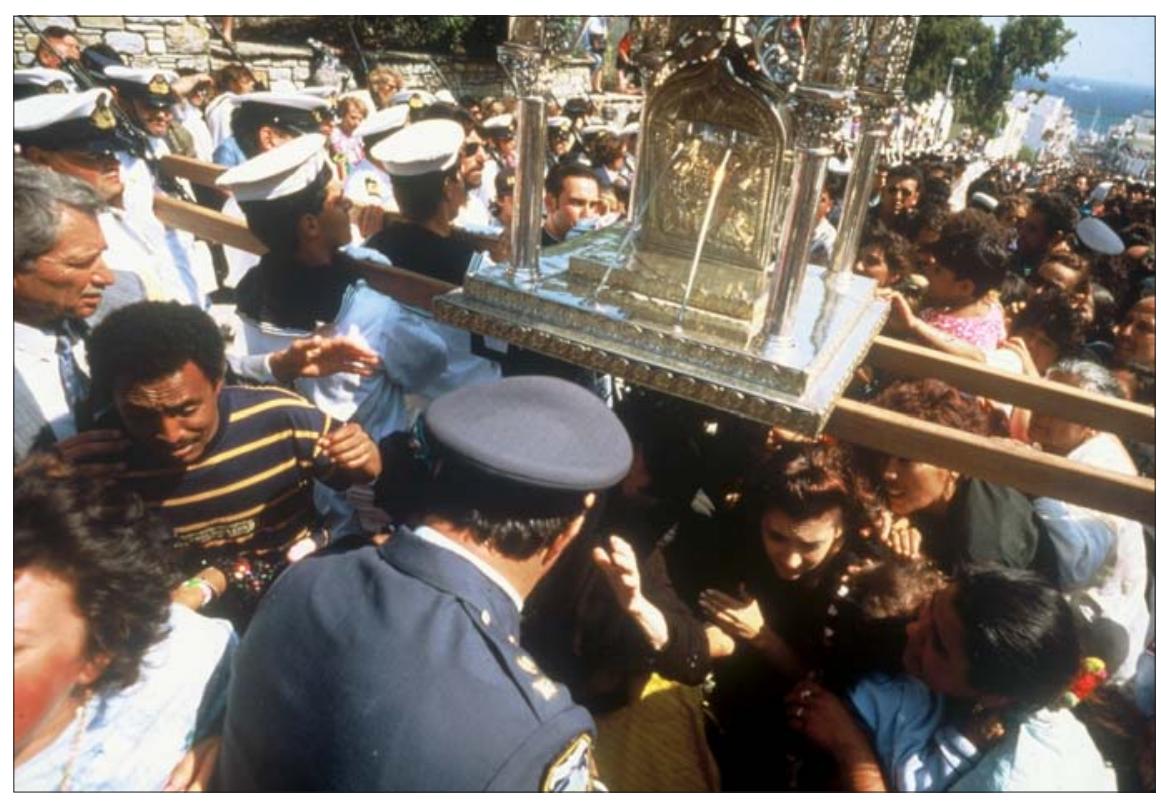

Figure 6. During the festival celebrating the Dormition of the Panagia (the Virgin Mary), on 15 August, her icon is carried in procession, and also over the sick and women wanting to conceive. Photo by Evy Johanne Håland. 
Figure 7. Saluting sailors in uniform, holding the icon depicting the Annunciation of the Virgin, during the ceremony at the harbour. Photo by Evy Johanne Håland.

Arriving at the harbour (Fig. 7) a service is followed by a speech given by the attending member of the Government, for example, the Foreign Affairs Minister, in 1993. The ceremony officially ends when the clergy and the officials go aboard a warship carrying them to the point where the Greek destroyer Elli was sunk by an Italian submarine as it was anchored off the Tinos harbour on 15 August 1940. Here, a religious service is held, and the priest and the president (i.e. in 1995) throw laurel crowns on the watery tomb of the ship and its crew. Meanwhile, the ships are sounding their horns, the jets are on a fly-past and people throng the coastline. "We came to pay honour to Panagia, who helped us to beat the fascists," said one of the survivors of the Elli crew in 1993. The importance of the Panagia and the Greek nation is also emphasized during the service, and she is begged in prayer to take care of the Greek nation as she has always done.

After the patriotic ceremony, the procession returns to the church at one o'clock. Mothers try to defy the police lines, to bring their sick children as close as possible to the icon. The aim of the procession is that the

Figure 8. The "9th day's ritual of the Panagia" starts on the eve of 23 August, Tinos island. Photo by Evy Johanne Håland.
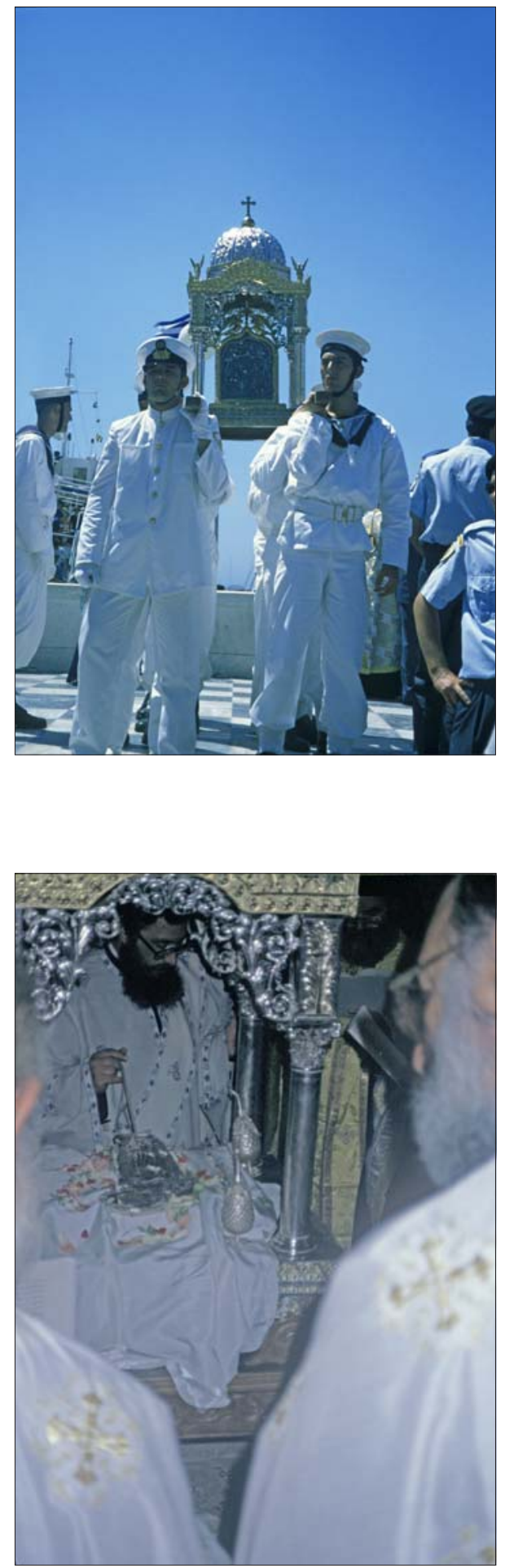
miraculous icon may pass over the pilgrims, to purify them for another year, and the Greek nation is also purified. In short, 15 August is a special day for Hellenism, combining religion with patriotism, and the Dormition on Tinos is a profound social event.

Panagia's death or Dormition is followed by her burial or the "9th day's ritual of Panagia" on 23 August (Fig. 8), thus, reflecting ordinary death-rituals and the following memorial service. The 15 August cycle ends with this memorial service taking place nine days after her death.

\section{THE MIRACULOUS ICON AND OTHER IMPORTANT SYMBOLS AND RITUALS}

The important symbol of the island, the Miraculous Icon of the Annunciation of the Virgin, said to have been made by St. Luke, belongs to all the festivals. During the festivals official processions carrying the icon in its midst are important, but there are also popular customs related to the importance of fetching holy water and earth, as well as other symbols which have a very long tradition within Greek religion, modern and ancient.

Accordingly, the ritual year of the miraculous icon on Tinos offers an interesting possibility to explore the relationship between official and popular religion.

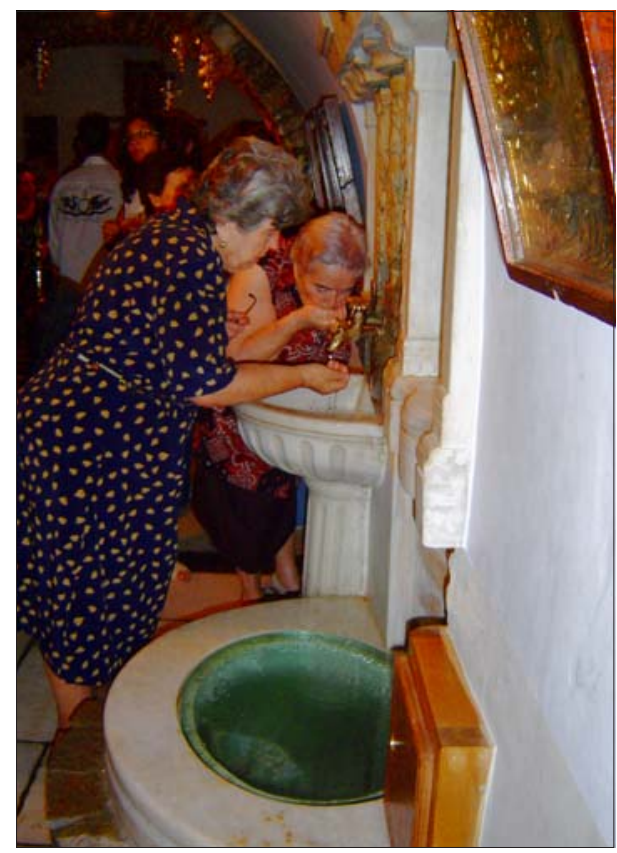

Holy water, agiasma, is found in most Greek sanctuaries, and some sanctuaries offer particular miracleworking water with its own legend attached to it. The sanctuary on Tinos has a chapel dedicated to the "Life-giving Spring”, and rituals connected with water are just as important as in all Greek churches. Below the main church at Tinos there are several smaller churches or chapels formed like caves, such as the aforementioned chapel dedicated to Pelagia

Figure 9. Pilgrims fetch holy, wonder-working water from "the Life-giving Spring" (Zōodochos Pēgē). Photo by Evy Johanne Håland. 
which is the second one. In the first chapel, however, is a holy spring, where the pilgrims fetch water, which has fertile power and cures sickness (Fig. 9). According to the tradition, the well was discovered in 1823, during the first excavations made in search of the holy icon, when the ruins of the foundations of the Byzantine Church were brought to light. The well was deep, but completely dry and useless. As no other well existed in the vicinity of the building site, on the day of the laying of the corner-stone of the church, the bishop sent a little boy to bring some water from the town for the celebration of the hallowing of the waters. Shortly afterwards, the child was back and told the bishop that the well next to the foundations was full of water. Having heard this, the bishop, accompanied by the notables went to the actual site and they saw with great surprise that the dry well was now filled to the brink with water. They made the sign of the cross for this miracle and afterwards took from the well the water necessary for the celebration of the hallowing. From that time, the water of the well has been used by the pilgrims as sacred water and everybody takes some along with her or him in special vials and keeps it at home as a talisman. Thus, the source is seen as a miracle and the chapel of holy water is called Zōodochos Pēgē, i.e. the 'Life-giving Spring'.

The pilgrims arrive in Tinos particularly after 1 August, the day on which the fifteen-day fast starts. People, mostly women, make their way up to the church barefoot, on their knees, or on their stomachs, and they bring with them various offerings, sometimes tied on their backs: candles as tall as the donor, icons, or wax. They may also bring incense, silver candlesticks, censers, bread, wine, sheep (particularly the gypsies). The most common offering is a silver or gold-plated ex-voto (tama / tamata) representing the person who has been miraculously cured by the icon, or the cured limb itself or the person or limb wanting to be cured, or a ship. The street, named Megalocharēs leads directly from the harbour to the church. Megalocharēs is a wide avenue about a kilometre in length, lined with shops and booths, particularly at its lower end. As soon as the pilgrims disembark from the ships and begin to make their way up the hill, they are assailed with the cries of the shopkeepers who stand outside their stores, hawking the items necessary for a successful pilgrimage: "Lampades! Tamata! Mpoukalakia gia agiasma! Edō Lampades!" (Large candles! Tamata! Little bottles for holy water! Here [are] large candles!').

At the top of the hill, when arriving at the doorway of the church, the pilgrims offer their large candles. Afterwards, they line up on the steps at the Church of the Annunciation, waiting their turn to enter the main chapel, to proskynema. Of particular importance are their devotions in front of the miraculous icon, being a microcosm since it is made of all substances of the world. It is especially important to kiss the icon itself, and one might also touch the 


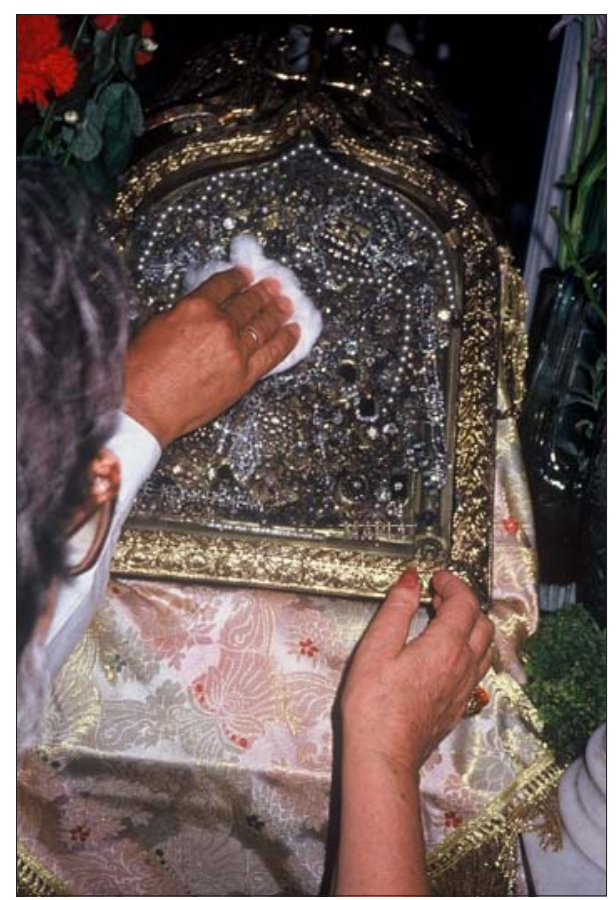

Figure 10. A pilgrim touches the icon with cotton wool, which afterwards is considered as an important amulet. Photo by Evy Johanne Håland.

icon with ex-votos to make them holy, or cotton wool, which afterwards is considered an important amulet (Fig. 10). Most of the pilgrims stay for a service, but even during services many pilgrims continue to move around, engaging in their own rituals.

Afterwards they descend to the chapel of holy water and earth beneath the church, since most pilgrims confine their attention to the main sanctuary and to the chapel of holy water below the church: "Where do we go for holy water?" pilgrims ask each other, and other more knowledgeable pilgrims direct them downstairs, to the chapel beneath the main church where they will find the holy water font. The pilgrims drop some money in a carved, slotted wooden counter, pick up candles to be lit, and inside the first chapel they kiss the icons, before they take some earth from the hole where the miracu-

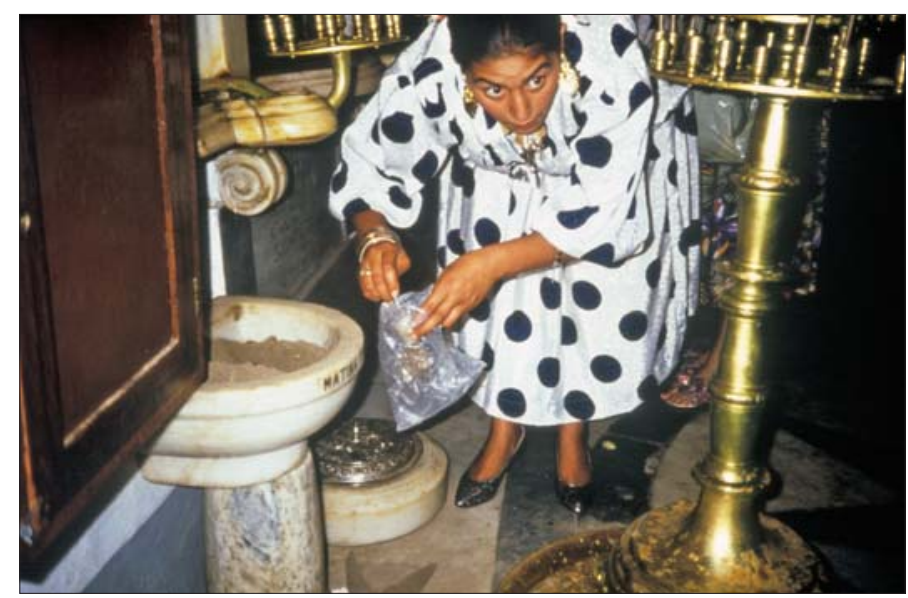

Figure 11. A pilgrim takes some holy earth from the hole where the miraculous icon was found. Photo by Evy Johanne Håland. 
lous icon was found (Fig. 11). Afterwards, they queue up to obtain holy water in small bottles or they drink directly from the tap. Many pilgrims only carry out the most important rituals and obtain the holy symbols before they return to the harbour.

On the eve of the feasts, the church is beautifully decorated and the icon might be placed on a blue and golden embroidered carpet as on the 14th of August 1990. During "the all-night-services" of the festivals many pilgrims spend the night inside the church, while the priests and cantors sing invocations. Simultaneously, many are occupied by fetching earth and water in the chapel below, both seen as important fertility and healing-remedies. During the festivals the earth and the water are considered to be particularly holy, when Panagia is so near. Accordingly, they are more powerful, and on the eve of her panegyrikos, the Dormition of the Panagia, many children are baptised in the chapel of holy water, in the "Life-giving Spring" (Håland 2007a: Fig. 15).

Particularly marriageable girls or newly married young women, fetch earth and holy water, to assure their own fertility and health.

The singing children, walking in procession with multicoloured lit lamps, are a general Greek custom during many winter-festivals (cf. Michaēl-Dede 1989). The July festival also presents several customs that are found in other summer-festivals, such as the outdoor lunch and the icon being carried between two sanctuaries, thus defining a sacred space. In particular, the Annunciation and the Dormition of the Panagia are important ideological festivals for the "New Greek nation-state of 1821", as illustrated through several ceremonies during the festivals, especially the processions when the icon is carried from the church to the harbour and the following ceremonies. In short, the days are special days for Hellenism, combining religion with patriotism.

\section{FROM THE RITUAL YEAR OF THE MIRACULOUS ICON ON TINOS TO THE WIDER MEDITERRANEAN AND BEYOND}

Many of the actual rituals and symbols, particularly the importance of fetching water and earth, as well as the pilgrimages and processions connected with deceased holy persons recur across several civilizations and religious groupings in the Middle East and Mediterranean areas. They might therefore be studied from a comparative civilizational perspective, thus transcending European heritages and liberating the ethnological imagination of Europe. 


\section{Death-cult}

The Orthodox Easter festival, dedicated to the Death and Resurrection of Christ, and the Dormition of the Panagia are the most important Pan-Hellenic death-

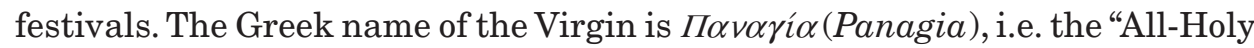
one", and reminds us that she is considered the most important intercessor and saint in the Greek tradition which emphasizes her maternal role as the Mother of God, rather than her Virginity. In the Orthodox Church, Mary is not seen as immaculately conceived and bodily assumed into heaven. Thus, the Orthodox Church celebrates her Dormition, rather than her Assumption, and she does not become a semi-deified human as in Catholicism (cf. Dubisch 1995; Economides 1986).

The festivals of Christian saints are also dedicated to dead persons who have the same mystical powers as the ancient mediators, heroes and heroines.

In the Greek cultural environment death-cult is the cult of dead familymembers and "great persons" through dedications of offerings and the performance of prayers on their tombs. Both the cult of newly deceased persons, and formerly dead heroes or heroines, bears witness of death-cult (Fig. 12).

We meet this phenomenon both in ancient and modern Greek society. The cult for holy men and women, who are dead, reveals itself through the ancient cult of the heroes, and the modern practice of sainthood in Christian areas. Ancestor-worship is the worship or propitiation of the ancestors. The cult of

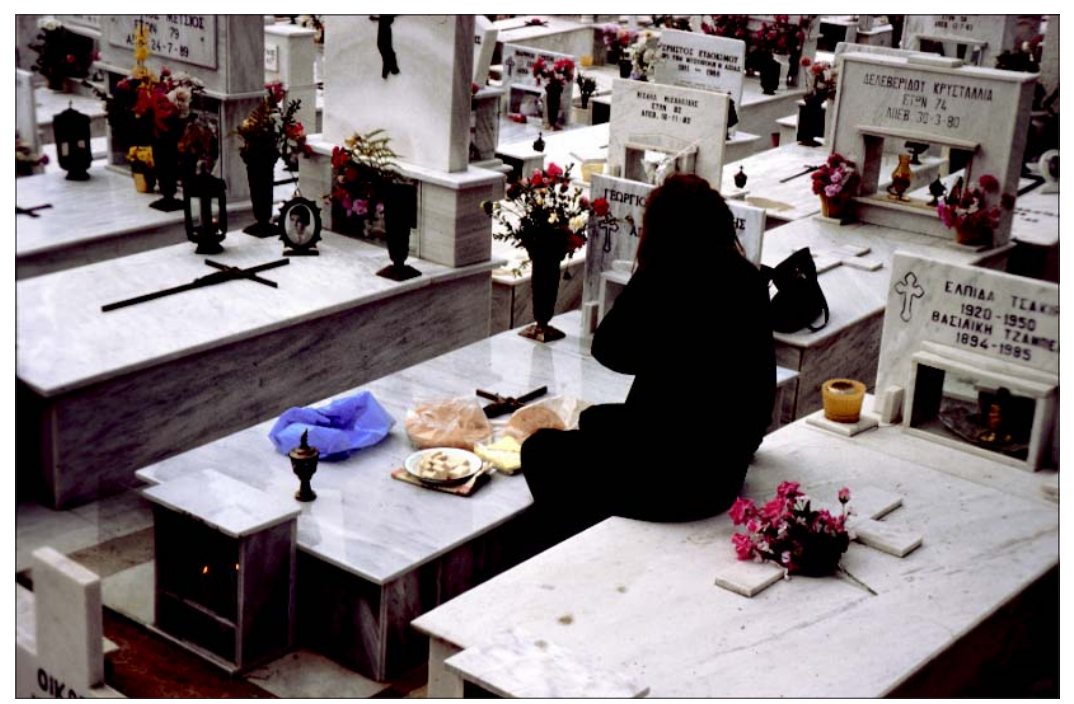

Figure 12. Memorial service performed for a deceased person with offerings of food at the tomb on the second of the three psychosabbata (i.e. psychosabbato, psychē 'soul', sabbato 'Saturday'), i.e. All Souls' Day, during Carnival and Lent, at the end of the winter, Serres (Greek Macedonia). Photo by Evy Johanne Håland. 
heros, heroines, and later, that of saints is the worship or propitiation of an important deceased person, man or woman. The phenomenon called deathcult is an important key in connection with most of the religious festivals. The reason is that the festivals very often are yearly memorials and celebrations dedicated to a deceased guardian of society. This guardian is a mediator between human beings and the supernatural within the hierarchical building that constitute the polytheistic-polydaemonistic society, in the same way as he or she often functioned when still alive, within human society.

The cult of the bones of dead mediators has a long tradition in Greek culture, such as the ancient heroes Orestes or Theseus (Herodotus 1.67-68; Plutarch Theseus 35-36; cf. also Pausanias 3.3.7), ${ }^{4}$ or the modern Agios Nektarios whose body - and especially his head - is particularly venerated on the island of Aegina on 9 November. On Tinos we also meet the death-cult in connection with the holy head of Pelagia, which resides in an ornate stand near the main entrance of her church, and through the glass top of the stand the dome of her skull can be seen (cf. Fig. 3). Pilgrims pay the same devotion to her head as to the miraculous icon, touching the glass top with similar votive offerings or objects they want to make holy, such as cotton, flowers, green leaves, candles, bread or cloth. Particularly during the festival, flower buds from the wreath of flowers decorating the stand are considered to be effective amulets after being crossed three times over her head. The same procedure is carried out in front of the figure depicting the Panagia on her deathbed (epitaphios) during the "9th day's ritual of the Panagia" (Håland 2007a: Fig. 26).

We meet the importance of death-cult in non-Christian areas as well, for example, in connection with the Turkish Mevlāna, and the marabouts (holy men) in North-Africa (Eickelman 1981), which means that this is related to fundamental rules, or long lasting mentalities in the Mediterranean. On its southern shore, one might mention the continuous fights over the tombs of Abraham, Sarah, Isaac, Rebecca, Jacob and Leah in the Cave of Machpelah in Hebron, the resting place of the Patriarchs and Matriarchs. Rachel's tomb and the Milk Grotto of Mary, formerly dedicated to the vegetation god, Adonis (Håland 2007a: ch. 5), illustrate two women's shrines in Bethlehem. There are several shared saints and festivals in the area (Cuffel 2005, 2009).

The most important festival of the Shî‘a is centred on the death of Husain, grandson of the Prophet. During this festival it is of greatest importance to make a pilgrimage to Husain's tomb in Kerbela, in Iraq (Grunebaum 1981). Saddam Hussein did not permit them to do this. His ban, however, was not new, since already several centuries earlier, people were forbidden to make pilgrimages to Husain's tomb, so one may ask if Saddam Hussein's move illustrates lack of historical knowledge: as early as in 850, the Caliph found it 
politically necessary to level Husain's tomb and to prohibit pilgrimages to Kerbela. Such an intervention by the government proved of little effect and the rebuilt grave has remained to this day the devotional centre for pilgrims from all over the Shî́a world. It is of particular popularity to be buried by the sanctuary, since they will surely enter Paradise. In the neighbouring country, the anniversary of Khomeini's death still draws huge crowds. After the fall of Saddam Hussein, the Shî‘a citizens were permitted to again make pilgrimages to Kerbela, as we could observe on television in 2003 (Håland 2004). When watching the pilgrims crawling and rolling up to the sanctuary of Kerbela, I started to think of my own fieldwork experiences from my time in Tinos, where the pilgrims arrive in the same way (Håland 2007a: Figs. 18-20), and where the builders of the church have their tombs in the church's courtyard. Below the main sanctuary of the church on Tinos there is also a mausoleum commemorating the sinking of the Elli. Every year, wreaths are placed to honour the heroes of the Elli and a service is given in front of the mausoleum on 13 August (Håland 2007a: Figs. 13-14). The principal and most important festival of the Shî́a is celebrated toward the end of the Muslim year, built around the death of Husain, thus paralleling the Dormition of the Panagia, when the greatest crowd of pilgrims arrive on the island to assure their fertility and health at the death of the Panagia by fetching holy earth and water, two important symbols in other places in the Mediterranean and Middle East as well.

\section{Water and Earth}

As already mentioned, the cultic importance of water and earth has a long tradition within Greek religion. Purification by earth was usual in certain ancient mystery cults, since clay and bran were smeared on the initiates, especially on their face, and then wiped off. Among the ancient stories are also those telling about the ceremonies exclusively performed by women when celebrating their goddesses, for example the pannychis, all-night festival and claydaubing of marriageable girls at the Artemis shrine at Ledrinoi, on the banks of the Alpheios river (Pausanias 6.22.8-9). From ancient Greece (Pausanias 9.17.4-6), we also learn about the importance of taking earth from a particular grave before the grain harvest and laying it on the tumulus of the heroine, Antiope to ensure the crop. In modern Greece holy earth from graves at the cemetery is also important, thus paralleling the holy earth from Panagia's sanctuary on Tinos which is seen as a powerful fertility and healing-remedy along with the holy water.

The clear bubbling water of a spring, rising out of the earth by a power, habitually regarded as a Water-Nymph, was, in the imagination of the ancient 
Greeks, a gift of the water deities, the goddesses by which all life on earth was fed. Water was considered to have therapeutic and purifying properties. Near the city at Odysseus' island was a

(...) fair-flowing fountain, wherefrom the townsfolk drew water (...), and around was a grove of poplars, that grow by the waters, circling it on all sides, and down the cold water flowed from the rock above, and on the top was built an altar to the nymphs where all passers-by made offerings. (Od. 17.208-212, cf. 240)

When Poseidon violated Demeter, in fact he coupled with her in the form of a stallion, she became angry. Though later she got over her wrath and wanted to wash in the river Ladon. According to Pausanias (8.25.6), this is how the goddess got her title, the Fury, because of her wrath, and Washing Demeter because she washed in the Ladon.

Strabo (8.6.8) tells that expiatory purifications were performed at the lake of Lerna, near which was the spring of Amymone. This is also where the heads of the murdered husbands of the Danaids were buried, according to tradition. In other words, they were buried in one of the Demetrian fruitful marshes, and thus married to the earth.

Paralleling the healing pools in modern Lourdes in Southern France, where Bernadette Soubirous (1844-1879), had several mystical visions in 1858 seeing the Virgin Mary appearing to her in a cave, thus paralleling the Tinos-legend (cf. Håland 2007b), one may mention the six water reservoirs in the Asklepieion, or sanctuary of Asklepios, of ancient Corinth. ${ }^{6}$ Their dimensions suggest that they were used to store water in summer when the springs ran low, and that the water was recycled for repeated use. It is also possible that water from the thermal springs at Thermà (Loutraki, cf. loutro i.e. 'bath') was transported to the Asklepieion in Corinth. Thus the Asklepieion at Therma (Loutraki) could have been a branch of the Corinthian Asklepieion. Six thermal springs bubble from the ground at Loutraki, and even in ancient times they were considered to be something special. Balneological analysis has shown that their water has a very high mineral content and is slightly radioactive. Rainwater was collected in one of the tanks. The total capacity of the water basins and reservoirs was about 341,406 cubic meters. In ancient times the water of the Fountain of Lerna was considered particularly wholesome and good, and its quality is comparable to that of the water from the Peirene Fountain (Athenaeus 4.156e).

Springs are often connected to healing and purification both in the ancient Greek and Graeco-Roman worlds and the modern Mediterranean. In ancient Greek written sources as in the modern Greek world, water is regarded and frequently mentioned in connection with exceptional powers. Water is also often dangerous, associated with water nymphs, the Nereids (cf. Blum \& Blum 1970; Håland 2005, 2007b). 
The Greek ritual carried out on "New" Friday, or Friday after Easter, which is dedicated to the Panagia under her attribute of the "Life-giving Spring" (Håland 2007b), is a part of the spring festivals, and may also be regarded as a purification ritual before the new season, which starts with the Resurrection of Christ. In this connection it may be compared to other purification rituals, such as the ones carried out in Persia, and under Persian influence in Iraq, Syria and Egypt, where the New Year was for some time celebrated in spring. ${ }^{7}$ In Persia, around $1008 \mathrm{AD}$, people went to the water of the aqueducts and wells. Frequently, they drew running water in a vase, and poured it over themselves, considering this a good omen and a means to keep off hurt. People also sprinkled water on each other, for which the cause was said to be the same as that of washing. According to another report of the same custom, the reason for it was that once after a long drought, rain fell on New Year's Day. People considered the rain a good omen, and poured it over each other. Afterwards the ritual remained among them as a custom that was carried out annually. Naturally, the water-sprinkling may have simply held the place of a purification by which people cleansed their bodies from the smoke of fire and from the dirt connected with attending the fires in winter.

Water has fertility-enhancing, healing, purifying and protecting powers; in the form of Holy Water, it is central to many rituals designed to ward off evil and to ensure blessings. It is also used in conjunction with different magical remedies. In an account from modern Greece it is said that the spring, at the Church of Christ at Spata, lends power to stones gathered there and these, added to holy water and passion flowers, make a charm which protects a house from illness.

An earlier account of sainthood in Islam gives interesting parallels with ancient and modern Greek customs in connection with death-cult. ${ }^{8}$ According to the British archaeologist, Sir Arthur Evans' description of the cult of a minor Muslim saint's sanctuary in the Southern Balkans (i.e. Albania), approximately a hundred years ago, the worshipper who would conform to the full ritual, fills a keg of water from a spring that rises near the shrine. In the centre of the grave is a hole, into which the water from the holy spring is poured, and thus mixed with the holy earth. Of this the votary drinks three times, and he must thrice anoint his forehead with it. Other rituals follow to shape the dreams of the faithful.

As already mentioned, springs are important in connection with the sanctuaries of Asklepios. But, long before he became famous, healing springs sacred to the Water-Nymphs and Artemis were widespread. Springs were also often connected with caves. According to Pausanias a ritual, performed in a Nymphs' cave containing sulphur springs, cured leprosy. ${ }^{9}$ 
Today, people from all over the world, come to Lourdes and Tinos, famous for their restoring capacities because of their holy healing and purifying waters, which the pilgrims take home. It is also important to point out the fact that the modern sanctuaries often are situated at places where ancient preChristian people also made pilgrimages to holy springs, for example in Greece, where Agia Marina of the Holy Springs has her church next to the ancient site of a temple holy to the goddess, Themis (Blum \& Blum 1970: 324) and the Panagia has replaced the Water-Nymphs in the Acropolis cave at Athens (Håland 2007b, cf. 2005).

In Pamukkale in Turkey, the excellent curative properties of the waters, known from ancient times in the neighbouring Hierapolis, where the Great Goddess was worshipped (Lucian Syr. D. 45-48), have permitted the construction in modern times of spas which are generally annexed to hotels in the area. Particularly, the ancient Romans appreciated this place.

Thus, water, and also earth have traditionally been important symbols in the wider Mediterranean and Near Eastern world as well as in the Greek contexts. The symbols were important in connection with the Persian wars in the 5th century BC, since the king of Persia set out to conquer all the Greek communities which refused to give him earth and water (Herodotus 6.94). The Greeks who refused thought these symbols were reserved for eternal divinities. Accordingly, they would not submit to a living person thus making him a god. On the other hand, the story illustrates that they shared a fundamental value-system, despite differing official political or religious ideologies. Today, the custom is a central element both in the church on Tinos and among Muslims in Istanbul where people dedicate to the religious leader water and earth, thus showing their submission. Afterwards, the same symbols are redistributed, thus paralleling the ritual surrounding bread (Fig. 13) within the Greek Orthodox Church, where the faithful also fetch water and earth. In

Figure 13. Offerings of bread, olive oil and wine, Markopoulo, Kephallonia island, 15 August. Photo by Evy Johanne Håland.

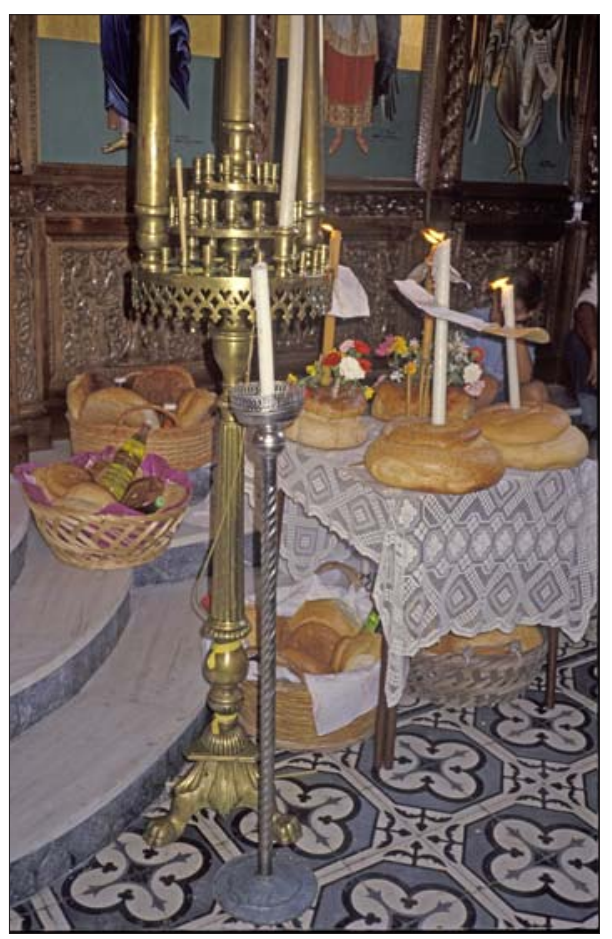


Istanbul, many of the fountains with holy water (agiasma), which were formerly associated with Greek Orthodox saints, are also adopted by Muslim believers (Sezim \& Darnault 2005). Springs are also of fundamental importance in general within Islamic rituals, since prayer is valid only when performed in a state of ritual purity, and therefore has to be preceded by ablution, wudú'. The duty of ablution accounts for the presence of fountains in the mosque courts, thus paralleling the Asklepian demand for ritual purity in ancient Greek culture, also seen in the modern importance of agiasma, for example in connection with the ritual year of the icon on Tinos.

\section{ACKNOWLEDGEMENTS}

I would like to thank The Norwegian Historical Association and Unifob Global at the University of Bergen, Norway, for giving me grants, thus providing me with financial support in connection with my participation in the 9 th SIEF Congress, Derry/Londonderry, Northern Ireland.

\section{NOTES}

${ }^{1}$ Since 1990, I have been engaged in several periods of fieldwork on Tinos particularly involving research into the festival dedicated to the Dormition of the Panagia on 15 August. On Tinos, I witnessed the festival in 1990, 1993-1998, 2004-2010. I have also carried out fieldwork on the festival dedicated to the "Vision" of Saint Pelagia (2005). Håland 2007a gives a comprehensive presentation and discussion of the Tinos-festivals, particularly the Dormition, as well as an extensive bibliography on the island and its history. See also 2006a, b and 2007b. The English translations of Greek texts, such as the pamphlet distributed by the church on Tinos, never translates Euangelistria with the Panagia of the Annunciation or the annunciated, but writes, for example, "The Church of the Annunciation (Euangelistria)". In general, people do not translate Euangelistria, cf. also infra concerning the street.

${ }^{2}$ See Meraklēs 1986: 178n.14 for the Euresēs-festival on 30 January and the relationship with invention of tradition, the customs, etc. and his citation from Phlorakē 1973. See also Håland 2007a: ch. 4 and 6 and particularly my forthcoming book for extensive discussions of older customs in new settings or modern recycling of ancient customs. The survival of values and beliefs, even though new normative religions have been introduced and the close relationship between the official Orthodox religion and popular religion, particularly in the rural parts of Greece, is further discussed in Håland 2005, 2007a: ch. 3. I disagree, therefore, with Meraklēs' assertion that the customs during the festival are new inventions. Although the Euresēs-festival is new, several of the customs in connection with this, and other festivals (such as the importance of fetching holy water and earth, etc.), have very long traditions within Greek culture, a fact which is also evident for Meraklēs as illustrated in his later reference to Katerina Kakouri (cf. Håland 2007a: 134). 
${ }^{3}$ Bent 1966 gives a vivid description of the festival in the 19th century, comparing it with ancient pilgrimages to the neighbouring sacred island of Delos, see also Håland 2007a: 113-114 for discussion.

${ }^{4}$ Abbreviations for ancient titles are listed with the respective references.

5 This aspect and the following topics from ancient Greek myths/culture are further discussed in Håland 2009.

6 The following is mainly based on Kasas \& Struckmann 1990.

7 The following draws on Grunebaum 1981: 54-55 quoted from al-Bīrūnī, who wrote ca. 1008. Cf. Håland 2005, for similar New Year rituals in Greece, i.e. in the beginning of January, but also the rituals after the Resurrection, Håland 2007b.

${ }^{8}$ For the following, cf. Evans 1901 and Håland 2004, cf. also 2005, 2007a.

9 Pausanias 5.5.11, cf. 9.40.1-2; cf. Håland 2009, see also 2005.

\section{REFERENCES}

Athenaeus 1928. The Deipnosophists. Vol. 2. Transl. by Ch. B. Gulick. London: The Loeb Classical Library.

Bent, James Theodore 1966 (1885). Aegean Islands: The Cyclades, or life among the insular Greeks. Chicago: Argonaut.

Blum, Eva \& Blum, Richard 1970. The Dangerous Hour. The Lore of Crisis and Mystery in Rural Greece. London: Chatto \& Windus.

Cuffel, Alexandra 2005. From Practice to Polemic: Shared Saints and Festivals as 'Women's Religion' in the Medieval Mediterranean. Bulletin of the School of Oriental and African Studies, University of London, Vol. 68, No. 3, pp. 401-419.

Cuffel, Alexandra 2009. Between Reverence and Fear: Jewish Women and Death in Medieval and Early Modern Ashkenaz. In: E. J. Håland (ed.) Women, Pain and Death: Rituals and Everyday-Life on the Margins of Europe and Beyond. Newcastle upon Tyne: Cambridge Scholars Publishing, pp. 143-169.

Dubisch, Jill 1995. In a Different Place: Pilgrimage, Gender, and Politics at a Greek Island Shrine. Princeton: Princeton University Press.

Economides, Irene 1986. Differences between the Orthodox Church and Roman Catholicism. Athens.

Eickelman, Dale F. 1981. Moroccan Islam: Tradition and Society in a Pilgrimage Center. Austin \& London: University of Texas Press.

Evans, Arthur J. 1901. Mycenean Tree and Pillar Cult and its Mediterranean Relations. Journal of Hellenic studies, Vol. 21, pp. 99-204.

Grunebaum, Gustave E. von 1981. Muhammadan Festivals. London: Curzon Press.

Herodotus (1926, 1950 [1920, 1922]). Vols. 1 and 3. Transl. by A. D. Godley. London: The Loeb Classical Library.

Håland, Evy Johanne 2004. En historisk analyse av sammenhengen mellom gresk dødekult i dag og i antikken. [An historical analysis of the relationship between Greek Death Cult, today and in the ancient world.] Historisk Tidsskrift Vol. 4, No. 83, pp. 559-591.

Håland, Evy Johanne 2005. Rituals of Magical Rain-Making in Modern and Ancient Greece: A Comparative Approach. Cosmos: The Journal of the Traditional Cosmology Society, Vol. 17, No. 2, pp. 197-251. 
Håland, Evy Johanne 2006a. The ritual year as a woman's life: The festivals of the agricultural cycle, life-cycle passages of Mother Goddesses and fertility-cult. In: G. Mifsud-Chircop (ed.) First International Conference of the SIEF working group on The Ritual Year. In association with The Department of Maltese University of Malta, Junior College, Msida, Malta, 2005: Proceedings. Malta: Publishers Enterprises Group (PEG) Ltd, pp. 303-326.

Håland, Evy Johanne 2006b. Athena's Peplos: Weaving as a Core Female Activity in Ancient and Modern Greece. Cosmos: The Journal of the Traditional Cosmology Society, Vol. 20, pp. 155-182.

Håland, Evy Johanne 2007a. Greske fester, Moderne og Antikke: En sammenlignende undersøkelse av kvinnelige og mannlige verdier. [Greek Festivals, Modern and Ancient: A Comparison of Female and Male Values.] PHD dissertation, University of Bergen 2004. Kristiansand: Norwegian Academic Press. An English version is forthcoming: Newcastle upon Tyne: Cambridge Scholars Publishing.

Håland, Evy Johanne 2007b. From Water in Greek Religion, Ancient and Modern, to the Wider Mediterranean and Beyond. Comparative Civilizations Review, Vol. 56, Spring, pp. 56-75.

Håland, Evy Johanne 2009. Take Skamandros, my virginity: Ideas of Water in Connection with Rites of Passage in Greece, Modern and Ancient. In: C. Kosso \& A. Scott (eds.) The Nature and Function of Water, Baths, Bathing, and Hygiene from Antiquity through the Renaissance. Technology and Change in History 11. Leiden: Brill Publishers, pp. 109-148.

Håland, Evy Johanne Forthcoming. Competing Ideologies in Greek Religion, Ancient and Modern (Konkurrerende ideologier i gresk religion før og nå). Haugesund: Alpha Press.

Kardamitsē, Iōannou N. 1992: To monastēri tēs Tēnou. Tinos: Ektē.

Karita, Elenē s.a. $\bar{E}$ Morphē mias Agias. Ē Pelagia tēs Tēnou. G. Ekdosē, Athens: Tēnos.

Kasas, Savas \& Struckmann, Reinhard 1990. Important medical centres in the antiquity: Epidaurus and Corinth. When the Medicine was still divine. Athens: Editions Kasas.

Lucian Syr. D. 1953 [1925] = De Syria Dea. Lucian. Vol. 4. Transl. by A. M. Harmon. London: The Loeb Classical Library.

Meraklēs, G. Michalēs 1986: Ellēnikē Laographia: Ēthē kai Ethima. Athens: Ekdoseis Odysseas.

Michaēl-Dede, Maria 1989. Kalanta, Kalēmera kai Thrēskeutika Tragoudia. Athens: Ekdoseis Philippotes.

Od. $=$ Homer 1946 [1919]. The Odyssey. Vol. 2. Transl. by A. T. Murray. London: The Loeb Classical Library.

Pausanias 1946, 1939 [1919]. Description of Greece. Vols. 2-4. Transl. by W. H. S. Jones. London: The Loeb Classical Library.

Plutarch Theseus = Plutarch. Lives 1948 [1914]. Vol. 1. Transl. by B. Perrin. London: The Loeb Classical Library.

Sezim, Sezer \& Darnault, Christophe 2005. Water and Religious Traditions in an Imperial City: Istanbul / Constantinople's Hagiasmas and Fountains. Paper presented at the 4th IWHA-Conference Water and Civilization: Water and Religion. Paris, December 2005, 17 pages. The paper is available on the conference CD, distributed by the IWHA secretariat (post@iwha.net).

Strabo 1954 [1927]. The Geography of Strabo. Vol. 4. Transl. by H. L. Jones. London: The Loeb Classical Library. 